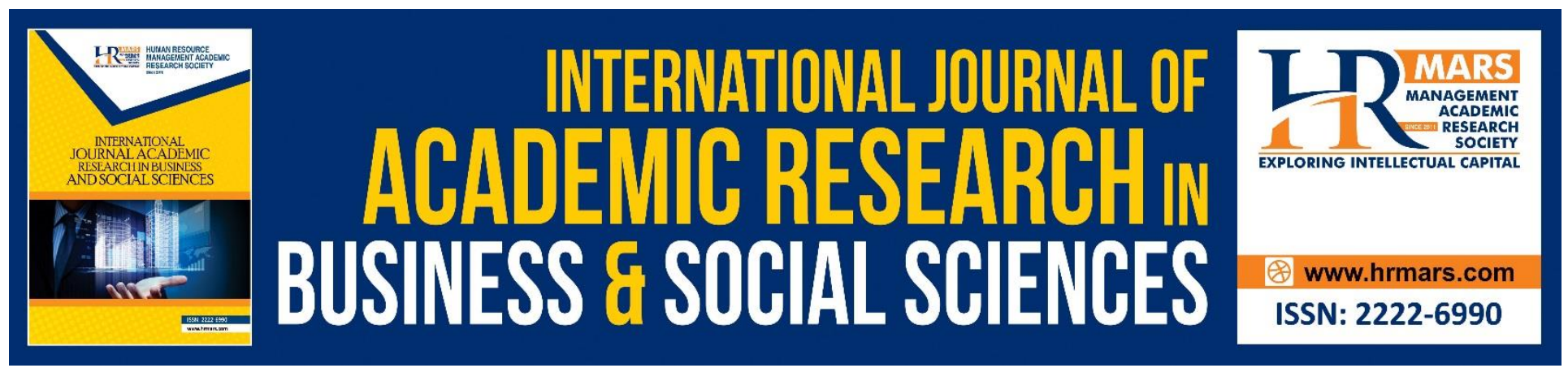

\title{
The Development of Islam and Mazhab Al-Syafi'i during the Post-Arrival of Islam in the Malay Archipelago
}

\section{Fathullah Asni}

To Link this Article: http://dx.doi.org/10.6007/IJARBSS/v9-i3/5789

DOI: $10.6007 /$ IJARBSS/v9-i3/5789

Received: 02 Feb 2019, Revised: 17 Feb 2019, Accepted: 30 March 2019

Published Online: 03 April 2019

In-Text Citation: (Asni, 2019)

To Cite this Article: Asni, F. (2019). The Development of Islam and Mazhab Al-Syafi'i during the Post-Arrival of Islam in the Malay Archipelago. International Journal Academic Research Business and Social Sciences, 9(3), 1196-1209.

Copyright: (c) 2019 The Author(s)

Published by Human Resource Management Academic Research Society (www.hrmars.com)

This article is published under the Creative Commons Attribution (CC BY 4.0) license. Anyone may reproduce, distribute, translate and create derivative works of this article (for both commercial and non-commercial purposes), subject to full attribution to the original publication and authors. The full terms of this license may be seen

at: http://creativecommons.org/licences/by/4.0/legalcode

Vol. 9, No. 3, 2019, Pg. 1196 - 1209

http://hrmars.com/index.php/pages/detail/IJARBSS

JOURNAL HOMEPAGE

Full Terms \& Conditions of access and use can be found at http://hrmars.com/index.php/pages/detail/publication-ethics 


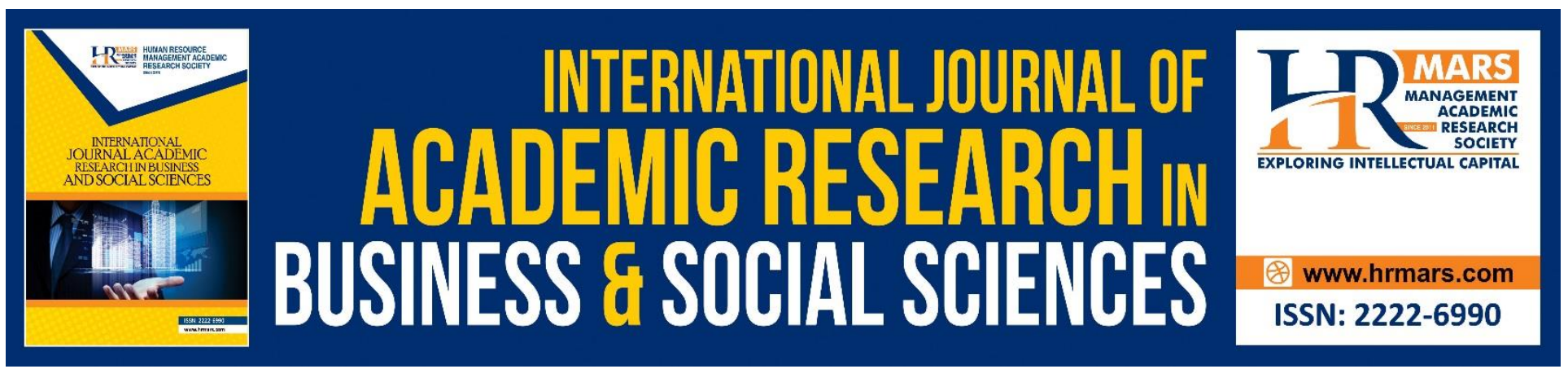

\title{
The Development of Islam and Mazhab Al-Syafi'i during the Post-Arrival of Islam in the Malay Archipelago
}

\author{
Fathullah Asni \\ School of Humanities, Universiti Sains Malaysia \\ Email: fathasni90@gmail.com
}

\begin{abstract}
The purpose of this study is to examine the factors of development of Islam according to the sect of al-Shafi'i in the Malay Archipelago during the post-Islam arrival. This study uses a qualitative method where the data are derived from literature studies i.e. referring to secondary sources such as books and journals. The data collected were analyzed using document and content analysis methods based on the objectives. The study found that the biggest factor in Islamization in the Malay Archipelago was because the royal family was entering into Islam, so it was also followed by subordinates because they were very loyal to the government. The study also found that many Arab preachers (da'i) who came to the Malay Archipelago were al-Shafi'i sect until it became a very strong factor in the spreading of the al-Shafi'i sect in the Malay Archipelago to produce many local al-Shafi'l sect scholars. Then the local scholars were appointed mufti and government advisors, the factor that led the sect of al-Shafi'i as an official sect in force over Muslims in the Malay Archipelago.

Keywords: Mazhab al-Syafi'i, Post-Arrival of Islam, the Malay Archipelago, Development of Islam, Malaysia

\section{Introduction}

The Malay Archipelago consists of several archipelago and territories, namely Sumatra, Jawa, Kalimantan / Borneo, Philippines, the Malay Peninsula and Mainland (Tanah Besar) (Borhan, 2014). The majority of the people in the Malay Archipelago are holding with religion of Islam where before the advent of Islam, the people were held with religion of Hindu-Buddhism. The high percentage of the Muslim was the beginning of the establishment of the Islamic sultanate in exchange for the previous Hindu-Buddhist system. The impact of the establishment of the Islamic sultanate as the rulers of the Malay Archipelago became Muslims had caused all the people to follow the religion of their kings. This is because the inhabitants of the Malay Archipelago are well-known for their souls
\end{abstract}


who were very loyal to the king's orders because of the influence of the Hindu-Buddhist religion in which they regarded the king as the incarnation of God on earth (Abdullah, 1989).

Recorded that the arrival of Islam in the Malay Archipelago region as early as the 7th century was at which time many popular schools (madhahib) were born like Hanafi, Maliki, Shafi'i, Hanbali, Zahiri, Shia and many more. However, in the various sects that were born in the Middle East in the centuries, Shafi'i sect became the dominant position in the affairs of the Islamic religion in the Malay Archipelago territory from the very beginning to this day. Hence, it is not surprising that the Malay Archipelago is synonymous with the Syafi'i sect. This is certain that there are several strong factors to highlight the Syafi'i sect in the Malay Archipelago. Therefore, this study is to examine the factors of Islamic development and the influence of Syafi'i school during the post-arrival of Islam in the Malay Archipelago region.

\section{The Arrival of Islam in the Malay Archipelago Region}

The Malay Archipelago consists of several archipelago and territories, namely Sumatra, Jawa, Kalimantan / Borneo, Philippines, the Malay Peninsula and Mainland (Tanah Besar) (Borhan, 2014). In the Malay Archipelago, there is a place known as Barus. Prior to the emergence of the Islamic kingdom in this region, Barus became the Arab-Farsi (Ta-Shih) village on the Northern Coast of North Sumatera in the 7th century AD. The Ta-shih group engaged in business activities in Barus in 674 AD (Abdullah, 1989; Yahaya \& Halimi, 1993). In this village, the community was led by an Arab named Abdullah Arif who taught Islam (Janaudin \& Adnan, 1991).

In addition to this opinion, there are other theories mention that the settlement of Ta-shih in 674 AD was not in Sumatera, but in Che-po or Java. The rise of this opinion was due to the occurrence of events in which those who lived in Che-po had met Queen Sima of the Kingdom of Kalingga (Holing) in East Java. There is even another assumption that the King of Ta-shih was the messenger to face Queen Sima, Muawiyah bin Abu Sufyan (661-680 AD) himself. This is because there are also reports of his attempts to attack Java in 674 AD (Abdullah, 1989).

However due to the existence of justice and security in the reign of Queen Sima, then his plan was canceled. In addition to Political purposes, there is also an opinion on the existence of an economic motive that prompted Muawiyyah to send a letter to Srivijaya in Jambi through Persian merchants, to invite him to embrace Islam and to establish a direct trade relationship with Damascus (Richards, 1970). If evaluated, it appears that these opinions are contrary to each other. But in the diversity of opinions, there is unity that all acknowledge the presence of Arab-Muslims in the Malay Archipelago in 674 or as early as the 7th century AD. Clearly, from the beginning in the 7th century AD (first century Hijrah), the Malay Archipelago already had Muslim groups. This explains the Arab and Persian trade relations with the Malay Archipelago region has already taken place before the advent of Islam (Borhan, 2014; Richards, 1970). The proof is that there is a small settlement of the Malay community in the port city of Aden in Yemen as early as 35 before AD (Shaffer, 2015).

Nevertheless, Islam entered the entire region began at Sribuza in 718 AD, Perlak in 840-986 AD, Samudera-Pasai in 1042-1450 AD, it was brought in by Syeikh Ismail al-Siddiq who held Shafi'i sect and his entourage coming from Mecca (Abdullah, 1989; Ishak, 1992). Acheh Darussalam in 1205-1675 
INTERNATIONAL JOURNAL OF ACADEMIC RESEARCH IN BUSINESS AND SOCIAL SCIENCES Vol. 9, No. 3, March, 2019, E-ISSN: 2222-6990 @ 2019 HRMARS

$M$ (Abdullah, 1989). While in the Java Archipelago, the entry of Islam in Giri was around before 1478 AD, Demak in 1478-1550 AD, Pajang in 1568-1586 AD, Mataram II in 1586-1755 AD (Abdullah, 1989). Then the arrival of Islam in the Malay Peninsula was started in Kelantan since the 7th century AD. This is because, Kelantan was once linked to Tan-Tan's name relating to China. But the establishment of the Islamic kingdom in Kelantan was in the 12th century AD (Abdullah, 1989). Kedah in 829 AD, however, the history of Islam's entry into Kedah was linked to the efforts of Syeikh Abdullah Yamani who held the al-Shafi'i sect to the Emperor Derbar II in 1137 AD (Abdullah, 1989; Yahaya \& Halimi, 1993; Gungwu, 1968). In Pahang around the 11th century AD (Yahaya \& Halimi, 1993). In Terengganu around 1303 AD, Melaka in 1414-1424 AD, in Johor around 1511 AD, in Perak around 1488-1511 AD (Abdullah, 1989).

While in the Philippine Islands especially in Sulu, Manguindanao and Manila were around from the 13th to the 15th century AD (Yahaya \& Halimi, 1993). In Borneo Islands, the inclusion of Islam in Brunei was in 1514-1521 AD (Yahaya \& Halimi, 1993). In the Mainland (Tanah Besar), this area is the strongest Hindu-Buddhist influence compared to other places (Yahaya \& Halimi, 1993). In Pattani, the entry of Islam in the 10th century or 11th century. While the entry of Islam in Siam was about 1350 AD (Yahaya \& Halimi, 1993).

There are many theories about the arrival of Islam in the Malay Archipelago that have been discussed by scholars. Some point out that Islam came from South India based on the tombstones similar to those found in Gujerat and Benggal as well as the presence of traders mostly from Gujerat, Coromandel and Malabar (Hamid, 1986). But Hamka (1994) and al-Attas (1990) mentions that Arabs, especially merchants who trade in the eastern region, have spread Islam to the region and evidently during the Umayyad and Abbasid dynasty that showed the Arabs already in the Malay Archipelago. This is because they have a strong navy that sailing easily to the eastern states (Azra, 2002; Hamid, 1986; Mukmin, 2004). According to old Malay sagas such as the Hikayat of the Pasai, Hikayat Acheh and the Malay History had mention the arrival of Arab as preachers to the region such as Sheikh Abdullah, Syeikh Ismail, Syarif Mecca who adhered to the sect of al-Shafi'i (Arnold, 1913). In addition, almost all religious writings in the Malay Archipelago came from the writings or references of Arab writers and not Indian or Chinese writers. This is evident when many local books referenced as the main source are from the Arabic writers by not showing the elements of Indianism (al-Attas, 1969). In conclusion, despite the fact that theories of Islam came from Arab, India and China, the rationale of the above theories was in the fact of the arrival of the Arab merchants to Southeast Asia (Janaudin \& Adnan, 1991). They were the first group to embrace Islam and spread it to the world including the Malay Archipelago on the principle of "al-risalah" (Shellebear, 1977). History shows Arab merchants leading to Southeast Asia through various ways of connecting either through the "Sea Silk Road" or "land Silk Road", via land to Afghanistan and then crossing into China to Canton directly to the Malay Islands. Some were either via the sea either directly from the Arab or stop in India then to Sri Lanka and continue to the Malay Archipelago (Mukmin, 2004). Partly by way of the sea either straight from the Arab or stop in India then to Sri Lanka and directly to the Malay Archipelago (Mukmin, 2004). As such, it is arguable that the three theories of the arrival of Islam to the Nusantara - from Arab, India and China - took place in the same century and all met in the Malay Archipelago. Each has played an important role in the spread of Islam in the places they had stopped (Borhan, 2014). 
INTERNATIONAL JOURNAL OF ACADEMIC RESEARCH IN BUSINESS AND SOCIAL SCIENCES

Vol. 9, No. 3, March, 2019, E-ISSN: 2222-6990 @ 2019 HRMARS

\section{Islamic Development in The Nusantara Region}

The Islamic scholars who came to the Malay Archipelago territory had invited the Malay community to Islam where the majority of Malay community were Hindus (al-Attas, 1969; al-Attas, 1966). They conveyed Islam in a scientific way i.e. emphasizing the logical proof of religious teachings. For example, the existence of Almighty God is evidenced by the existence of this nature (Abdullah, 1989; al-Attas, 1969; al-Attas, 1966; Mukmin, 2004; Arba'iyah, 2011).

In addition to the divine concept, it also conveyed the concept of brotherhood, equality, eliminating the caste system and the simplicity of Islam (Ripin, 2003). Furthermore, during the spread of Islam, Islamic scholars did not impose any coercion (Ripin, 2003). In an effort to spread Islam in the Malay community, scholars such as Abdullah Arif at Acheh and Sayyid Abdul Aziz in Melaka had done some ways and methods to attract more Malays to Islam (Shellebear, 1977). Among the early tasks were the teaching of religious knowledge in the palaces, learning Malay language and culture, and some of them marrying locals (Fatimi, 1963; al-Attas, 1985).

Mixed marriages were among the dynamic methods of intermarriage, whether Islamic traders with locals or fellow royal families will form a Muslim community that plays an important role in educating and promoting Islam (Mukmin, 2004). Through their charismatic and high-performance appearance apart from wealth have led the governments and the local people to accept Islam easily and confidently (Mukmin, 2004). In addition, the Islamization of Pasai was due to its government, Sultan Malikus Saleh, with the Princess Ganggang from Perlak who had previously embraced Islam. He was invited to Islam by a Muslim scholar named Syeikh Ismail (Mukmin, 2004). Some of them were married to the royal family to get a special position in the government such as Ali Ibn Muhammad Jaafar Sadiq who married the daughter of Perlak (Zarif, 2011).

Although traditionally royal families can only marry royal families and were not allowed to marry subordinates, not to mention outsiders. However, because the castles were very interested in the appearance and morality showed by the Arabs, then there were groups of castles allowing their daughters to marry Arab merchants and preachers. This is more convenient for them to spread Islam as well as teach religion to local people (Azra, 2002). Indirectly, the spread of Islam among the rulers was also followed by subordinates where they were very loyal to the government (Azra, 2002). Parameswara's marriage with Puteri Pasai had made much good for both governments. Melaka and Pasai often exchanged representations to study aspects of Islamic theology. The proof is that there are several books in Melaka palace such as Hikayat Saidina Hamzah, Hikayat Muhammad Ali Hanafiah, Hikayat Amir Hamzah (Mukmin, 2004). Another example is the marriage of Sultan Mansur Shah with Princess Majapahit, Raden Galoh Cendera Kirana and Princess Hang Li Po from China (Hamid, 1986). Also, the element of education is also not neglected where the development and continuity of Islamic law are closely related to the community commitment of the faithful to it. The determination of society to practice it cannot be realized unless the community understands its methods of practice. Hence, on this basis, the scholars have provided education through religious studies in the palaces and mosques (Arba'iyah, 2011, Hassan, 2000).

The proof of religious studies in the palace can be seen that Maulana Abu Bakar brought a theology (usuluddin) mixed tasawuf written by his teacher a Sufi named Abu Ishaq titled Durr al-Manzum to 
Sultan Mansur Shah (1459-1477) at the palace of Melaka (Wan Ali, 1973; Cortesao, 1994). He then ordered that the book is brought to Pasai palace for further clarification and interpretation before being brought back to Malacca for his study (Hamid, 1983; Winstedt, 1969). This is because Pasai is known as an early government to accept Islam and popular in terms of religious and Malay-Islamic studies (Hill, 1960; Hamid, 1983; Winstedt, 1969; Fatimi, 1963; Bakar, 1976). This book was later interpreted by a Pasai scholar named Tuan Pemataan or Tuan Patakan after being accounted for by Sultan Pasai (Ahmad, 1958; Winstedt, 1969). The famous Book of Durr al-Manzum since the time of Sultan Mansur Shah was then studied by the castles such as Sultan Alauddin Riayat Shah by Maulana Abu Bakar and his son Raja Ahmad or Muhammad (Sultan Mahmud Shah) taught by Maulana Sadar Jahan (Hooker \& Basri, 1991; Hashim, 1990; Cortesao, 1994; Hamid, 1983).

The sequence of the influence of this religious study then other kingdoms such as Malacca, Acheh, Riau and so forth which rose after Pasai also did so. At this time, religious studies not only in theology but also in the field of tasawwuf and figh (Syariah) law, affecting the minds of some Malay monarchs and historians (Sham, 1995). Thus, the outcome of the spread of Islam has attracted nobles to embrace Islam as well as having a strong influence in shaping the Islamic kingdom. In this early period, the Islamic religious department was not specifically designated because the government was established as a center of Islamic rule whereby the Sultan would execute islamic legislation and advised by the mufti. Therefore, it is important for the government to embrace Islam as they will rule the country according to Islamic law.

\section{The Role of Ulema in Producing Islamic Kingdom}

Among the effective tactics performed by Islamic scholars are the main focus of inviting kings to embrace Islam. This is because the kings are the head of government and have the absolute power, then when the rulers embrace Islam, it can change from the old system to the Islamic administration system, this certainly has a greater impact on the spread and consolidation Islam. In addition, it is a short way for the local community to embrace Islam because they are very devout and obedient to the kings. Thus, if the rulers change their religion, they will do the same (Hassan, 2000).

In fact, the responsibility to invite (da'wah) to Islam is based on the continuation of the da'wah which has been carried out by Rasulullah SAW. The da'wah has been conducted since the 8th century AD (Yahya \& Halimi, 1993). During the Khalifah Umar bin Abdul Aziz (717-720 AD) was sending the preachers (da'i) to Southeast Asia was actively carried out. In 720 AD, he succeeded in inviting the Government of Suwarnabhumi Kingdom or the Jambi Malay named Sri Indravarman to embrace Islam. Sri Indravarman is a Srivijaya emperor whose name is known as China's Shih-li-t-'o-pa-mo. In $100 \mathrm{H}$ (718 AD), Emperor Srivijaya sent a letter to Khalifah Umar bin Abdul Aziz and asked him to send a cleric to explain about Islam. Later, the Majapahit kingdom changed its name to Sribuza Islam (Yahya \& Halimi, 1993).

Additionally, around the year 820 AD, a group of preachers of the Shia Mazhab came from Gujerat had arrived at Perlak. It is noted in an old Malay text entitled Izhar al-Haq fi Mamlakah Perlak written by Abu Ishaq al-Makarani al-Fasi. The delegation had successfully invited the rulers and residents of Perlak to enter Islam and make it the first Islamic government in Southeast Asia. One of the preachers named Ali Ibn Muhammad Jaafar Sadiq, he was married to the princess of the Perlak palace. The first prince of his marriage was Syed Maulana Abdul Aziz Shah who was later installed as the first Sultan 
in the Perlak Sultanate in 840 AD. Therefore, in this early stage, Islam spread across the northern coast of Sumatra is the Shia mazhab (Zarif, 2011; Abdullah, 1989; Abdullah, 1985).

By the 10th century $\mathrm{CE}$, the situation of the Islamic world became messy and weak. The collapse of the Abbasid Kingdom caused the regions under its authority to liberate themselves. The wars to seize the territory among the smaller kingdoms often occur. This chaotic situation has resulted in a handful of Muslim societies alienating from the public and living as Sufi members who practice tarikah and tasawuf. The members of the tarikah then went out to spread Islam in their way. They played an important role in the spread of Islam in the 13th century AD and later in the Malay Archipelago (Yahya \& Halimi, 1993).

Around 1260 AD, a messenger from Makkah led by a Sufi scholar named Syeikh Ismail al-Siddiq came to spread Islam in Southeast Asia. Together with him was a Sufi cleric from Malabar India, named Fakir Muhammad. At that time, he had succeeded in bringing the Samudra-Pasai king to embrace Islam (Abdullah, 1989). According to the Hikayat of the Pasai Kings and the Malay History, they had spread Islam in Lamburi (Acheh), Perlak and Pasai. In Pasai there had also mazhab Syafi'i scholars came from Persia like Syarif Amir Sayyid al-Syirazi and Tajuddin al-Asfahani, so they produced scholarly figures such as Syeikh Said Sari who had successfully invited King Patani to embrace Islam (Batutah, 2003; Teeuw \& Wyatt, 1970). It was also recorded by Ibn Battuta when visiting Pasai, during the reign of Sultan Malik al-Zahir, he found that the king administered the government with Islamic law, he also met two scholars from Persia namely al-Syirazi and al- Asfahani (Batutah, 2003).

During the 15th century AD, Malacca had a great role in spreading Islam in the archipelago in general and in the Malaysian peninsula, in particular replacing Pasai (Winstedt, 1969). Malacca was very prominent when Parameswara converted to Islam and founded the Islamic kingdom (Yacob, 1990; Yahaya \& Halimi, 1993; Mukmin, 2004). At that time, a trader from Jeddah led by a scholar, Sayyid Abdul Aziz, who was held a Shafi'i mazhab, had stopped the port of Malacca. The delegation had succeeded in inviting the king and the great people of Malacca to embrace Islam (Shellebear, 1977). Then, Parameswara married Puteri Raja Pasai (Perlak) named Puteri Ratna Keumala who also had converted to Islam (Mukmin, 2004). Parameswara succeeded in developing Malacca as the center of Islamic rule. This led to the presence of many scholars in Malacca like Makhdum Sayyid Abdul Aziz, Maulana Abu Bakar, Kadi Yusof, Kadi Menua, Kadi Munawar Syah, Maulana Sadar Johan consisting of various races such as Bengali, Arab, Pasai, Gujarati and Persia (Shellebear, 1977). They were appointed government advisors and discussed religious issues and made the palace, the surau and the mosque as a center of study and dissemination of knowledge (Hall, 1961). The next government continued this effort.

The impact of the active role of these scholars had affected the state administration with the formulation of the Malacca Code of Law and the Malacca Sea Law based on a mixture of Islamic teachings and local customs whose influence comes from Pasai (Hooker, 1984; Winstedt, 1969). The law is compiled by the Royal Seri Nara and had influenced to other state laws as well as Pahang law, Johor law, and Nine-Tenth Laws in Perak (Muhammad, 1996; Hamid 1986; Majid, 1997). Malacca Malay Sultanate system chart (Hassan, 2000): 
INTERNATIONAL JOURNAL OF ACADEMIC RESEARCH IN BUSINESS AND SOCIAL SCIENCES Vol. 9, No. 3, March, 2019, E-ISSN: 2222-6990 @ 2019 HRMARS

\begin{tabular}{|c|}
\hline Islamic Judicial System \\
Court Structure \\
Malacca Sultanate (1400-1511) \\
\hline Sultan \\
\hline Mahkamah Balai \\
\hline Mufti (Advisor) \\
\hline $\begin{array}{c}\text { Bendahara Temenggung Laksamana Syah Bandar Hulubalang } \\
\text { Panglima Mandulika Nakhoda Penghulu }\end{array}$ \\
\hline Administrative Officer / Law Enforcement \\
\hline
\end{tabular}

During the height of Malacca's state development, the state empire covered the entire Malay Peninsula and several areas in East Sumatra namely Jambi, Siak, Rokan, Inderagiri, Kampar, Bangkalis, Karimun, Bentan and Riau. During the reign of Sultan Mansur Shah (1456-1477), Malacca was approached by a Maulana named Abu Bakar from Jeddah carrying a book of Dur Mazlum which deals with tasawuf. Then the book was sent to Pasai for translation into Malay. Sultan Mansur Shah and court officials studied with Maulana Abu Bakar. He emphasized religious issues. He had also established a mufti position in which his incumbent was an Arab scholar (Winstedt, 1969). Their position was higher than other palace officials (Hassan, 2000). Among them were Kadi Yusof, Kadi Manua and Kadi Menawar Syah (Winstedt, 1938). Their role is to advise the administration on religious affairs and Islamic law and to be the sultan's adviser (Hassan, 2000). Due to the vast knowledge of the Sultan of Mansur about Islam, he had succeeded in bringing many Cambodians (Campa) into Islam (Mukmin, 2004).

During the reign of Sultan Alauddin Riayat Syah (1477-1488M), he was a very fair man, he had one night out to arrest a thief with his two escorts Hang Isap and Hang Siak. He also implemented Islamic law such as law of hand cut (Hashim, 1990; Hamid, 1986). Similarly, when Sultan Mahmud Syah ruled Malacca (1488-1511M), he emphasized the teachings of Islam. He was willing to walk to learn Islam from Maulana Sadar Johan, he also ordered palace officials to study Islam with Maulana Sadar Johan. Due to the fact that there were many Islamic scholars who specialize in Malacca, Islamic scholars from other states came to Malacca to explore religious knowledge and Islamic jurisprudence such as Wali Songo (Javanese), Sunan Bonang and Sunan Giri (Winstedt, 1969). Sultan Alauddin Riayat Syah invited the rulers of Inderagiri, Pahang and Kampar together with their families to study about Islam in Malacca. This had led Islam and Islamic empire to expand throughout the Malay Archipelago. In fact, the Malacca government sent Islamic scholars to subdivisions of colonies covering Pahang, Terengganu, Kedah, Pattani, Johor, Kelantan, Kampar, Siak, Rokan, Inderagiri, Siantan, Kepulauan Riau-Lingga, Jambi, Dinding, Selangor, Muar, Batu Pahat, Singapura, Bentan, Perak, Kelang and Pahang to establish the administration of Islam and implement Islamic law based on the law of Malacca (Winstedt, 1969). Among the local Islamic scholars born is Tun Muhammad who was held Syafi'i mazhab, a specialist in fiqh and fluent in Arabic language as a result of the development of many Islamic law experts comprising Arabs, Indians and Persians until the late 15th century, then the 
local Islamic scholars replaced the position of outside scholars as either teachers, mufti, qadi or author of the Islamic books (Winstedt, 1969; Hassan, 2000).

After the collapse of the Malacca government, the center and dissemination of knowledge moved to the Acheh Darussalam (1205-1675). The kingdom was founded by Johan Syah in 1205 and reached its golden age during the reign of Sultan Ali Mughayat Syah (1511-1530) (Hassan, 2005). This is because, the traders moved to Acheh. The Acheh Kingdom was the center of Islamic administration and education at that time, especially in the 17th century AD where many scholars were there both locally and from outside Acheh, among them was Sheikh Nuruddin al-Raniri, he was appointed as mufti (Hasjmy 1982. Winstedt, 1969). They had produced many students who then return to their respective places throughout the Malay Archipelago, including in Malaysia. In Acheh was born three great figures of Acheh scholars who were Syafi'i mazhab at that time. They were Nur al-Din al-Raniri, 'Abdul Rauf Singkel and Jalal al-Din al-Tursani. They were the clerics who had held the position of Syeikh al-Islam. Nur al-Din al-Raniri wrote the book al-Sirat al-Mustaqim, a fiqh book in the Shafi'i sect which describes special worship laws such as prayers, fasting, zakat and pilgrimage (Rahman, 2006; Rahman, 1995). This book is considered as the first book written in the Malay Archipelago, i.e. in 1634 and it is plated from the books of Syarh al-Minhaj by Zakaria al-Ansori, Mughni al-Muhtaj by al-Syarbini, Tuhfah al-Muhtaj by Ibn Hajar al- Haithami and Nihayah al-Muhtaj by al-Ramli (Sharif \& Ahmad, 1993; Abdullah, 1985; Ngah, 1995; Abdul, 2004). It is among the earliest and largest Islamic legal writings in Malay which is not a canonical law and it is regarded as an Islamic law which regulates the fiqh of the Malay Archipelago community (Bakar, 1976). This book was written during the longlived al-Raniri in Pahang before he came to Acheh (Abadi, 1979). 'Abd al-Ra'uf Singkel wrote his popular book, Mir'at al-Tullab, a book in the Shafi'i School, which is more complete than the book of al-Raniri. It contains descriptions of muamalat, munakahat and jinayat, which is more relevant to the social life in 1672 (Sharif \& Ahmad, 1993). While Jalal al-Din al-Tursani wrote the book Safinat alHukkam which contains conversations about muamalat, jinayat and debates related to the government and administration of the country. The book was written during the reign of Sultan Alaudin Johan Syah (1735-1760) (Sharif \& Ahmad, 1993). Among the purposes it was written to guide the rulers in issuing laws and fatwa, so the content was al-Qada' (the court) (Hasjmy, 1982).

Besides them, there were some other Islamic scholars in Acheh among them was Jamal al-Din alTursani, son of Jalal al-Din. He wrote the book Hidayat al-'Awam, a fiqh book which began with the description of "'isyrun sifah lillah". Another character is also called Jalal al-Din. He had written the book of Fara'id al-Qur'an, which is about the law of inheritance. Another is Muhammad Zain Ibn Jalal al-Din who wrote the book of Kasyf al-Kiram, which is about the intentions (niyyah) and takbirah alIhram in solah, and also the book of Talkhis al-Falah which describes the law of marriage and divorce. The writings of 'Abd al-Ra'uf Singkel and Jalal al-Din al-Tursani had a high impact on Islamic studies in the Malay Archipelago region, including in Malaysia. This is because the two books had taken into account local approaches to guide local communities including rulers, administrators and judges (Hasjmy, 1982).

The writings on figh in the Shafi'i sect produced by the Acheh Scholars had spread throughout the Malay Archipelago and became a reference for a long time. The spread not only occurs through education networks but also through conquest. Among the states that received the influence of Islamic studies from Acheh were Minangkabau presented by Burhan al-Din, a student of 'Abd al-Ra'uf 
Singkel. Meanwhile, the states which received Acheh's influence through conquest were Johor in 1615, Pahang in 1618, Kedah in 1619 and Perak in 1620. In Kedah, when it was under the reign of Sultan Muzafar Syah, King Acheh had sent two books to him. The two books are al-Raniri's essay entitled al-Sirat al-Mustaqim and Bab al-Nikah (Salleh, 1972). Hence, these books are a reference in the administration of Islamic religion in that area.

Later, local Islamic scholar's figures were born outside Acheh. Among them are 'Abd Malik bin Abdullah (1736), a scholar from Terengganu state famous for the title "Tok Pulau Manis". He had studied with Abdul Rauf Singkel in Acheh and later with Sheikh Ibrahim al-Kurani (1616-1690), Abdul Rauf's teacher in Mecca. His essay was given the name as Risalah Naql and Risalah Kaifiyyah Niyyah. The first book on the right number of jama'ah in Friday prayer by qawl qadim and qawl jadid in Mazhab Shafi'i. While the second book is about "intentions" in worship. Then born a great cleric in the state of Banjar, Sheikh Muhammad Arsyad al-Banjari (1710-1812). After studied in Mecca for 30 years, he returned to Banjar and later became the mufti of the state during the reign of Sultan Tahmidullah who was also his best friend. One of his works in fiqh is Sabil al-Muhtadin Li al-Tafaqquh Fi Amr al-Din in 1781. The two volumes were written on the order of the Sultan Banjar at that time, Sultan Tahmidullah Ibn Sultan Tamjidullah (Sharif \& Ahmad, 1993). This book contains only the problem of worship, which is the same as the book of Nur al-Din al-Raniri, al-Sirat al-Mustaqim (Sharif \& Ahmad, 1993).

In Patani was born a scholar named Syeikh Daud bin Abdullah al-Fatani. He studied in Mecca and lived there for a long time. He wrote many books, but the special about fiqh is the book of Furu 'al-Masa'il which is a complete fiqh book in the al-Shafi'i sect. The book discusses the aspects of worship, muamalat, munakahat, jinayat and so on. According to Abdullah (1989), this book is due to its complete character as the top work in the field of figh in the Malay Archipelago at that time (Sharif \& Ahmad, 1993). Also, there are also other scholars is Muhammad Ibn Isma'il Dawud al-Fatani. Among his popular books are Matla' al-Badrayn which was first published in Mecca in 1882. In Kelantan was born a scholar, Abd Samad bin Muhammad Saleh, who is best known for the title of Tuan Tabal (1840-1891). Among the books he wrote were Kifayat al-'Awam and Hidayat al-Ta'lim al'Awam. Muhammad al-Badawi al-Sambawi who is also famous for his book Siraj al-Huda. Among other books is Thamarat al-Muhimmah by Raja Ali Haji. Besides, the book of Kifayat al-Ghulam written by Ismail Minangkabau, Kifayat al-Mubtadi by Muhammad Noor bin Muhammad bin Ismail al-Fatani, and also Kitab al-Fatawa written by Ahmad bin Muhammad Zain Ibn Mustafa al-Fatani (Abdullah, 1985).

These writings and teachings had made sharia studies based on the Mazhab Shafi'i so synonymous throughout the Malay Archipelago. In other words, when it comes to Islamic law, then what is meant is that based on the Shafi'i Mazhab. In addition to the fields of study and practice, this school also became the basis of the formation of the bureaucracy of religious administration. All government officials in the field of religion such as mufti, imam, qadi and so on were holding in the Syafi'i sect. Similarly, all laws and regulations relating to the religion of Islam are based on the Syafi'i sect. All this has facilitated the implementer to administer Islam as there are many scholars and reference books based on the al-Shafi'i sect. Therefore, it may be said in this early age, many scholars play their role in the field, some who are advisers to the Sultan in the palace, some who write books, teach in mosques and open centers of study. The sequence of teaching at the mosques and the centers of 
study, then the community's issues of Islamic affairs will be answered by the scholars according to the Shafi'i sect. The Sultan is the judge who will punish those who involve major and complex mistakes under Islamic law. All this is an integrated effort in creating and strengthening a newly established Islamic government (Majid, 2007).

\section{Conclusion}

Although historians differ in opinion about the arrival of Islam in the Malay Archipelago as some, say it comes from India, China or Arab with diverse proofs and theories, but the most reliable opinion is that it begins with preachers coming from Arab to Southeast Asia to spread Islam because they have embraced Islam since the beginning. The acceptance factor of Islam is also easy when preachers are wise in delivering Islamic teachings so that it is easy to be accepted by the local community. Among the approaches taken is to approach the nobles through marriage and business as the average preachers are also the merchants. Having been approached through marriage and business relations, it facilitates the palace to embrace Islam. When the castles have been embrace Islam, it is also followed by the people as it is understood that the local community is very loyal to the government. Among the factors of development of the al-Shafi'i sect in the Malay Archipelago are because the preachers who come were holding the sect of al-Shafi'i, then indirectly the spreading of Islam is based on the sect of al-Shafi'i. The influence of the al-Shafi'i sect is also increasingly strong when local clerics who held the al-Syafi'i sect also can be born, then they will fill mufti positions to implement the alShafi'i sect in the public field. Local scholars also found writing religious reference books based on alShafi'i sect. This makes the sect of al-Shafi'l survive as the dominant sect in the administration of Islam until today. Hence, it can be concluded that the significant factor in the development of the alShafi'i sect in the Malay Archipelago was due to the presence of the al-Shafi'i preachers from the Middle East.

Hence, it is found that the practices of worship (ibadah) and muamalat of the Muslim community in Malaysia especially today are based on the sect of al-Shafi'i. This study intends to propose future studies on the influence of other sects such as Hanafi, Maliki and Hanbali in Malaysia as the laws of Islamic administration in the states also recognize these sects to be a source of the fatwa.

\section{Corresponding Author}

Fathullah Asni

School of Humanities, Universiti Sains Malaysia, 11800 Pulau Pinang, Malaysia

Email: fathasni90@gmail.com

\section{References}

Abadi, J. (1979). Sari Sejarah Kesusasteraan Malaysia-Indonesia (Tradisi-Moden). Kuala Lumpur: Penerbitan Abadi.

Abdullah, A. R. H. (1989). Islam dalam sejarah Asia Tenggara tradisional. Kuala Lumpur: Penerbitan Pena.

Abdullah, M. S. (1985). Perkembangan Ilmu Figh dan Tokoh-Tokohnya di Asia Tenggara (Vol. 1). Solo: Ramadhani.

Ahmad, A. A. (1958). Sejarah Kesusasteraan Melayu. Kuala Lumpur: Dewan Bahasa dan Pustaka 
INTERNATIONAL JOURNAL OF ACADEMIC RESEARCH IN BUSINESS AND SOCIAL SCIENCES

Vol. 9, No. 3, March, 2019, E-ISSN: 222 2-6990 @ 2019 HRMARS

Al-Attas, M. N. (1969). Preliminary statement on a general theory of the Islamization of the MalayIndonesian Archipelago (Vol. 22). Dewan Bahasa dan Pustaka.

Al-Attas, N. (1966). Raniri and the wujudiyyah of 17th century Acheh. Singapore: MBRAS.

Al-Attas, S. F. (1985). Notes on various theories regarding the Islamization of the Malay Archipelago. Alatas, SF (1985). Notes on Various Theories Regarding the Islamization of the Malay Archipelago. The Muslim World, 75, 162-175.

Al-Attas, S. M. N. (1990). Islam Dalam Sejarah dan Kebudayaan Melayu. Petaling Jaya: Angkatan Belia Islam Malaysia (ABIM)

Arba'iyah, M. N. (2011). Perkembangan Pensejarahan Islam di Alam Melayu, Jurnal al-Tamaddun Bil. 6

Arnold, T. W. (1913). The preaching of Islam: a history of the propagation of the Muslim faith. Constable.

Azra, A. (2002). Jaringan Global dan Lokal Islam Nusantara. Bandung: Mizan

Bakar, S. A. (1976). Institusi Shaykh'Abdu'I-Malik bin'Abdu'llah (satu corak pengajian tradisi di Terengganu) dan kitab-kitab padanya. Master Thesis, Institut Bahasa, Kesusasteraan dan Kebudayaan, Kuala Lumpur: Universiti Kebangsaan Malaysia

Batutah, I. (2003). Pengembaraan Ibnu Batutah (trans.), Kuala Lumpur: Institut Kefahaman Islam Malaysia (IKIM)

Borhan, A. J. (2014). Islam di Nusantara. Prosiding. Kolokium Islam Pahang 'Meraikan Ilmu' organized by Pahang State Museum at Tun Razak Stadium, Sultan Abu Bakar Museum, Pekan, Pahang on 18 March 2014

Cortesao, A. (1994). The Suma Oriental of Tome Pires. London: The Hakluyt Society.

Fatimi, S.Q. (1963). Islam Comes to Malaysia. Singapore: Malaysia Sociological Research Institute.

Gungwu, W. (1968). The first three rulers of Malacca. Journal of the Malaysian Branch of the Royal Asiatic Society, 41(1 (213), 11-22.

Hall, D. G. E. (1961). A History of South East Asia. London: Oxford University Press

Hamid, I. (1983). The Malay Islamic Hikayat. UKM: Institut Bahasa

Hamid, I. (1986). Perkembangan Islam di Asia dan Alam Melayu. Kuala Lumpur: Heinemann (Malaysia) Sdn. Bhd.

Hamka, A. K. (1994). Sejarah Umat Islam. Singapura: Pustaka Nasional

Hashim, M. Y. (1990). Kesultanan Melayu Melaka: kajian beberapa aspek tentang Melaka pada abad ke-15 dan abad ke-16 dalam sejarah Malaysia. Dewan Bahasa dan Pustaka.

Hasjmy, A. (1982). Naskhah-naskhah Tua Menyimpan Alam Fikiran Melayu Lama: Sebuah Studi Tentang Safinat al-Hukkam. Prosiding. Simposium Kesusasteraan Melayu Tradisional, Universiti Kebangsaan Malaysia

Hassan, A. A. (2000). Pertumbuhan Pentadbiran Undang-Undang Islam Malaysia, in Mohd Taib Osman and A. Aziz Deraman, Tamadun Islam di malaysia, Kuala Lumpur: Dewan Bahasa Dan Pustaka

Hassan, A. A. (2005). Pengajian dan Pengamalan Undang-Undang Islam di Malaysia: Antara Tradisi dan Moderati. Kuala Lumpur: Universiti Malaya

Hill, A. H. (1960). Hikayat Raja-Raja Pasai. Journal of the Malayan Branch of the Royal Asiatic Society, 33(2 (190), 1-215. 
INTERNATIONAL JOURNAL OF ACADEMIC RESEARCH IN BUSINESS AND SOCIAL SCIENCES

Vol. 9, No. 3, March, 2019, E-ISSN: 222 2-6990 @ 2019 HRMARS

Hooker, M. B. (1984). Islamic Law in Southeast Asia. Singapore: Oxford University Press

Hooker, V. M., \& Basri, A. F. (1991). Tuhfat Al-Nafis: Sejarah Melayu-Islam. Dewan Bahasa dan Pustaka.

Ishak, A. (1992). Islam di India, Nusantara dan China. Kuala Lumpur: Nurin Enterprise.

Janaudin, J \& Adnan, R. A. (1991). Sejarah Islam: India-Nusantara-China. Kuala Lumpur: Penerbitan Elman.

Majid, M. Z. H. A. (1997). Pengantar Undang-Undang Islam di Malaysia. Kuala Lumpur: Universiti Malaya

Majid, M. Z. H. A. (2007). Mazhab Syafi'i di Malaysia: Sejarah, Realiti dan Prospek Masa Depan. Jurnal Fiqh, 4, 1-38.

Muhammad, A. K. (1996). Sejarah Penulisan Hukum Islam Di Malaysia. Kuala Lumpur: Dewan Bahasa Dan Pustaka

Mukmin, M. J. (2004). Melaka Pusat Penyebaran Islam di Nusantara. Melaka: Institut Kajian Sejarah dan Patriotisme Malaysia (IKSEP)

Ngah, M. N. (1995). Islamic World View of Man, Society and Nature Among the Malays. Singapore: Institute of Southeast Asian Studies.

Rahman, M. A. (2004). Sheikh Nuruddin al-Raniri dan Kitabnya Sirat al-Mustaqim. Prosiding. Seminar on Manuskrip Islam, organized by Brunei Prime Minister's Office, at Berakas, Brunei on 1-2 March 2004.

Rahman, M. J. (1995). The Malay Law Text. Kuala Lumpur: Dewan Bahasa dan Pustaka.

Rahman, M. M. (2006). Riwayat Hidup Syeikh Nuruddin al-Raniri dan Sumbangannya Kepada IImu Hadith. Kuala Lumpur: Dewan Bahasa dan Pustaka.

Richards, D. S. (1970). Islam and the trade of Asia: a colloquium (Vol. 2). B. Cassirer.

Ripin, M. M. (2003). Tamadun Islam \& Tamadun Asia 1. Johor: Universiti Teknologi Malaysia.

Salleh, Z. M. (1972). Hikayat Merong Mahawangsa. Kuala Lumpur: Dewan Bahasa dan Pustaka.

Shaffer, L. N. (2015). Maritime Southeast Asia to 500. Routledge.

Sham, A. H. (1995). Hukum Kanun Melaka. Penerbitan Perbadanan Muzium Melaka. Melaka: Perbadanan Muzium Melaka

Sharif, Z. \& Ahmad, J. (1993). Sastera Melayu Tradisional. Kuala Lumpur: Dewan Bahasa dan Pustaka. Shellebear, W.G. (1977). Sejarah Melayu. Kuala Lumpur: Penerbit Fajar Bakti Sdn. Bhd.

Teeuw, A., \& Wyatt, D. K. (1970). Hikayat Patani. In Hikayat Patani the Story of Patani (pp. 68-145). Springer, Dordrecht.

Wan Ali, W. M. (1973). Suntingan dan Anotasi Sebuah Kitab Tasawwuf Melayu Kurun Ketiga Belas Hijrah/ Kedelapan Belas Masihi: ad-Durru'n-Nafis. Master Thesis, Institut Bahasa, Kesusasteraan dan Kebudayaan. Kuala Lumpur: Universiti Kebangsaan Malaysia.

Winstedt, R. (1969). A History of Classical Malay Literature. Oxford: Oxford University Press

Winstedt, R. O. (1938). The Malay Annals of Sejarah Melayu. Journal of the Malayan Branch of the Royal Asiatic Society, 16(3 (132), 1-226.

Yacob, A. F. (1990). Sejarah Islam. Kuala Lumpur: Pustaka Pelajaran

Yahaya, M., \& Halimi, A. J. (1993). Sejarah Islam. Kuala Lumpur: Penerbit Fajar Bakti Sdn. Bhd.

Zarif, M. M. M. (2011). Satu Milenium Islam di Nusantara: Tinjauan Sosio-Sejarah. Prosiding. Konvensyen Wasatiyah Sempena 1 Milenium Islam di Nusantara on 9-11 June 2011 at Putrajaya 
INTERNATIONAL JOURNAL OF ACADEMIC RESEARCH IN BUSINESS AND SOCIAL SCIENCES

Vol. 9, No. 3, March, 2019, E-ISSN: 222 2-6990 @ 2019 HRMARS

organized by Universiti Sains Islam Malaysia (USIM) and Nadi Dialog Malaysia (NADI) in collaboration with n collaboration with JAKIM. 